\title{
PERENCANAAN STRUKTUR DERMAGA PETI KEMAS KAPET BATULICIN, DI KALIMANTAN SELATAN
}

\author{
Zainal Abidin $^{1)}$, Fahrurarid ${ }^{2)}$, Bambang Kiswono ${ }^{3)}$ \\ ${ }^{1)}$ Prodi Teknik Sipil, Fakultas Teknik, Universitas Muhammadiyah Surabaya \\ JL. Sutorejo No. 59 Kota Surabaya, Jawa Timur, 61135 \\ E-mail: allzaby@yahoo.co.id \\ ${ }^{2}$ Prodi Teknik Sipil, Fakultas Teknik, Universitas Muhammadiyah Surabaya \\ JL. Sutorejo No. 59 Kota Surabaya, Jawa Timur, 61135 \\ E-mail: fahruraridthamrin@gmail.com \\ ${ }^{3)}$ Prodi Teknik Sipil, Fakultas Teknik, Universitas Muhammadiyah Surabaya \\ JL. Sutorejo No. 59 Kota Surabaya, Jawa Timur, 61135 \\ E-mail: bambangkiswono.48@gmail.com
}

\begin{abstract}
The KAPET Batulicin area which has been designated as a National Strategic Area (NSA) based on PP No.26 of 2008 , has the potential to develop superior commodities based on natural resources, especially plantations, production forests, iron or mining, and aquaculture and capture. But unfortunately the infrastructure (port), especially the port serving containers is still unavailable. The existing port is a port that serves coal transportation and is owned by private parties. So it is necessary to plan a container dock that is expected to be able to support economic progress and prosperity in the Batulicin region. This dock is planned to be able to serve container ships with a maximum draft of 50,000DWT. This type of dock structure is an open wharf with trestle as a link between the stacking field and the pier. Pile foundation using JIS A 5525 steel piles. In planning this dock structure, the structural system is analyzed using the SAP2000 program with 3D models. The loading and reinforcement of the structure is controlled based on SNI regulations and BMS 1992. From the results of the design planning is obtained, the dock consists of a jetty head building and 2 trestles. The dimensions of the jetty head are $720 \mathrm{~m}$ long and $50 \mathrm{~m}$ wide. The dimensions of the pier beam are $80 \mathrm{~cm}$ wide and $120 \mathrm{~cm}$ high, while the pile dimensions are $1016 \mathrm{~mm}$ diameter, $19 \mathrm{~mm}$ thick and $20.65 \mathrm{~m}$ long for upright piles and $20.75 \mathrm{~m}$ for tilting piles with $6 \mathrm{~V}$ : $1 \mathrm{H}$ slope ratio. The pile cap dimension for a single pole is $1.5 \times 1.5 \times 1.2 \mathrm{~m}$. Pile cap dimensions for double poles are $3 \times 1,4$ $\mathrm{x} 1,4 \mathrm{~m}$. The structure used is the fender type V $400 \mathrm{H}$ and the BR-150 bollard structure.
\end{abstract}

Keywords: Port, Dock, Container, Pile

\begin{abstract}
Abstrak
Wilayah KAPET Batulicin yang telah ditetapkan sebagai Kawasan Strategis Nasional (KSN) berdasarkan PP No.26 Tahun 2008 , memiliki potensi pengembangan komoditas unggulan berbasis pada sumber daya alam, terutama perkebunan, hutan produksi, pertambangan bijih besi, serta perikanan budidaya dan tangkap. Namun sayangnya prasarana (pelabuhan) khususnya pelabuhan yang melayani peti kemas masih belum tersedia. Adapun pelabuhan yang sekarang ada merupakan pelabuhan yang melayani pengangkutan batu bara dan meruapakan milik pihak swasta. Sehingga perlu adanya perencanaan dermaga peti kemas yang diharapkan akan mampu menunjang kemajuan perekonomian dan kesejahteraan di wilayah Batulicin. Dermaga ini direncanakan mampu melayani kapal petikemas dengan draft kapal maksimal 50.000DWT. Tipe struktur dermaga ini adalah wharf terbuka dengan trestle sebagai penghubung antara lapangan penumpukan dengan dermaga. Tiang pondasi menggunakan tiang pancang baja JIS A 5525. Dalam perencanaan struktur dermaga ini, sistem struktur dianalisis dengan menggunakan program SAP2000 dengan model 3D. Pembebanan dan penulangan struktur dikontrol berdasarkan peraturan SNI dan BMS 1992. Dari hasil perencanaan desain didapatkan, dermaga terdiri dari bangunan jetty head dan 2 buah trestle. Dimensi dari jetty head yaitu panjang $720 \mathrm{~m}$ dan lebar 50m. Dimensi balok dermaga yaitu lebar $80 \mathrm{~cm}$ dan tinggi $120 \mathrm{~cm}$, sedangkan dimensi tiang pancang diameter $1016 \mathrm{~mm}$, tebal $19 \mathrm{~mm}$ serta panjang $20,65 \mathrm{~m}$ untuk tiang pancang tegak dan $20,75 \mathrm{~m}$ untuk tiang pancang miring dengan perbandingan kemiringan $6 \mathrm{~V}: 1 \mathrm{H}$. Dimensi pile cap untuk tiang tunggal yaitu $1,5 \times 1,5 \times 1,2 \mathrm{~m}$. Dimensi pile cap untuk tiang ganda yaitu $3 \times 1,4 \mathrm{x} 1,4 \mathrm{~m}$. Pada struktur sandar yang dipakai adalah Fender tipe V 400 H L=200 serta struktur bollard BR-150.
\end{abstract}

Kata kunci: Pelabuhan, Dermaga, Petikemas, Tiang pancang

\section{PENDAHULUAN}

Penyelenggaraan jasa kepelabuhanan memiliki peran yang strategis dalam upaya mewujudkan kehidupan masyarakat yang lebih sejahtera. Dalam konteks ekonomi, pelabuhan merupakan modal bagi pertumbuhan perekonomian, dan sebagai katalisator antara proses produksi, pasar, dan konsumsi akhir yang dibatasi oleh kondisi alam suatu daerah atau wilayah. Keberadaan pelabuhan memberikan gambaran tentang kemampuan daerah dan kemampuan produksi masyarakat. Keberadaan pelabuhan laut juga berperan sebagai instrumen bagi pembuka daerah terisolasi, dan memperkecil kesenjangan antar wilayah. Ketersediaan sarana dan prasarana (infrastruktur) kepelabuhanan juga dapat mendorong terciptanya kesempatan kerja dan berusaha. Dengan kata lain, pelabuhan laut merupakan basic determinant atau kata kunci bagi perkembangan ekonomi daerah dan nasional. 
Kabupaten Tanah Bumbu adalah salah satu kabupaten di provinsi Kalimantan Selatan, Indonesia. Kabupaten ini merupakan daerah yang mempunyai sumber daya yang perlu dikembangkan untuk pengembangan daerah Kalimantan selatan khusunya dan Indonesia pada umumnya. Kawasan pengembangan ekonomi terpadu KAPET Batulicin merupakan salah satu kapet yang ada di Indonesia berlokasi di kawasan kabupaten Tanah Bumbu dan kabupaten Kotabaru. KAPET Batulicin merupakan suatu wilayah yang diarahkan untuk peningkatan pertumbuhan ekonomi yang berbasis pada industry yang didukung dengan berbagai infra struktur penunjang seperti adanya pelabuhan samudra dan kondisi jalan yang memadai. KAPET Batulicin yang telah ditetapkan sebagai Kawasan Strategis Nasional (KSN) berdasarkan PP No. 26 Tahun 2008, memiliki potensi pengembangan komoditas unggulan berbasis pada sumber daya alam, terutama perkebunan(kelapa sawit dan karet), hutan produksi (perkayuan), pertambangan bijih besi, serta perikanan budidaya dan tangkap.

Namun sayangnya prasarana (pelabuhan) angkutan laut kawasan kabupaten Tanah Bumbu dan kabupaten Kota baru umumnya serta wilayah Batulicin khususnya masih belum maksimal karena kebanyakan pelabuhan yang sudah ada merupakan pelabuhan yang dimanfaatkan untuk keperluan pengankutan batubara saja dan juga merupakan milik perseorangan. Hal inimengakibat kanpotensi perkebunan (kelapa sawit dan karet), hutan produksi (perkayuan), pertambangan bijih besi, serta perikanan budidaya dan tangkap yang ada di pulau tersebut belum dapat dimaksimalkan dengan baik. Oleh Karena itu perlu adanya pembangunan sarana dan prasarana (pelabuhan) angkutan laut sebagai perintis jalur transportasi laut . Dimana sarana dan prasarana (pelabuhan) terdiri atas dermaga dan fasilitasnya.Dermaga harus direncanakan sedemikian rupa sehingga kapal dapat merapat dan bertambat serta melakukan kegiatan di pelabuhan dengan aman, cepat dan lancar. Sebuah dermaga akan menerima berbagai macam beban diantaranya; beban gelombang air laut, beban angin, beban arus, beban benturan kapal, berat dermaga, berat fasilitas diatas dermaga, dan sebagainya. Pada tahap perancangan tentunya beban - beban tersebut harus dianalisa oleh perancang Kekuatan struktur pada tahap perancangan harus diperhitungkan, namun tidak melupakan aspek ekonomisnya.

\section{METODELOGI}

Berikut adalah diagram alir perencanaan dermaga peti kemas KAPET Batulicin, Kabupaten Tanah bumbu, Provinsi Kalimantan Selatan dapat dilihat pada gambar
1.
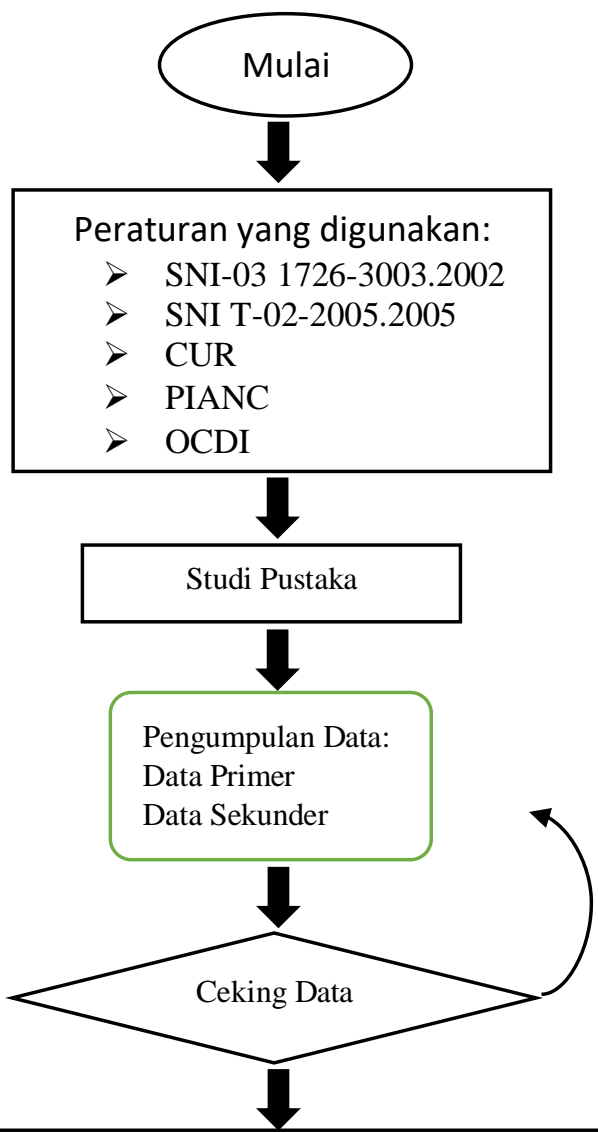

Analisa Data:

Topografi, Angin, Gelombang, Pasang surut, Arus, Tanah

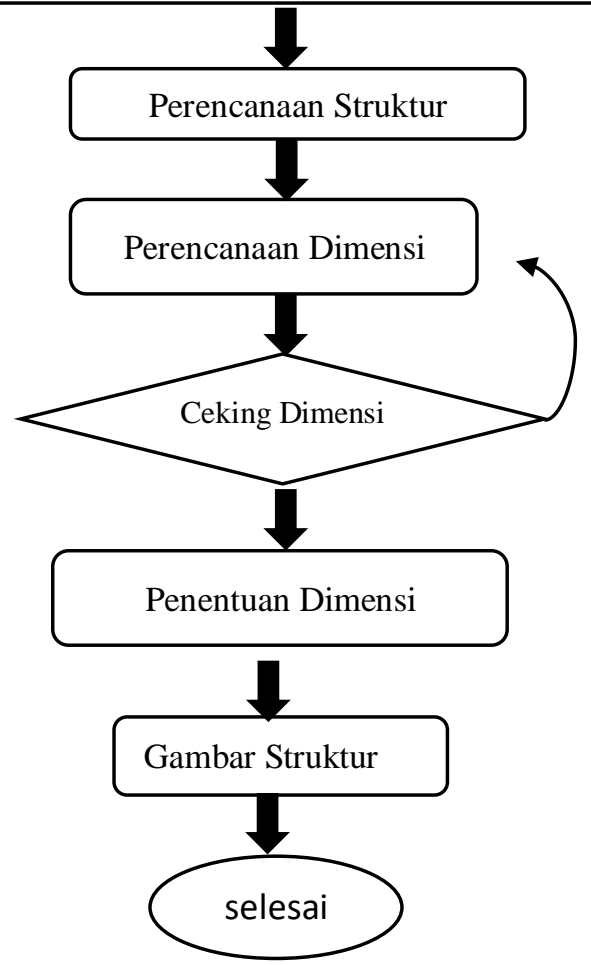

Gambar 1. Diagram alir perencanaan dermaga Sumber : Analisis Data (2018) 


\section{Analisis data}

Analisis data meliputi hal-hall sebagai berikut:

1. Data Bathymetri

Peta bathimetri digunakan untuk mengetahui kondisi gelombang di lokasi. Data bathimetri diperlukan untuk membuat peta bathimetri untuk mengetahui profil bawah laut dan lokasi dermaga. Pengetahuan mengenai profil bawah laut berguna dalam tinjauan daerah perairan yang menyangkut luas, kedalaman perairan, alur pelayaran, penambatan, tempat labuh dan kemungkinan pengembangannya di masa mendatang.

Untuk melihat profil kedalaman lebih detail maka di buat profil melintang kedalaman pada beberapa lokasi perairan, yakni perairan Pelabuhan Samudera Batulicin, Pelabuhan Ferry ASDP, Tanjung Kersik, Teluk Pagatan, Tanjung Pagatan dan Tanjung Petang, sebagaimana disajikan pada Gambar 3.2. Dari beberapa profil tersebut menunjukkan bahwa kedalaman yang memiliki kedalaman yang cukup dalam terdapat pada perairan Tanjung Kersik dapat mencapai $>20 \mathrm{~m}$.

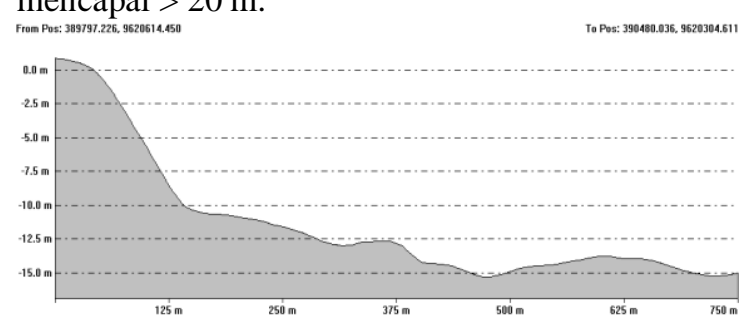

Gambar 2Potongan melintang kedalaman laut yang ditarik tegak lurus dari garis ke lautPelabuhan Batulicin Sumber: Pengolahan data (2013)

\section{Data Angin}

Data arah dan kecepatan angin maksimum bulanan diperoleh dari data BMKG Stagen untuk cakupan wilayah Kabupaten Tanah Bumbu tahun 2001 - 2013, yang kemudian dianalisis untuk menentukan frekuensi dan persentase kecepatan angin sebagaimana disajikan pada Tabel 3.1, sedangkan Gambar 3.4 adalah windrose berdasarkan data dalam Tabel 3.1. Berdasarkan gambar dan tabel tersebut diperoleh arah angin bulanan maksimum dominan dari selatan $(26,9 \%)$, kemudian dari arah barat $(18,6 \%)$ dengan kecepatan dominan berkisar pada interval 5,4 - 7,9 m/s (42,3\%), sedangkan kecepatan maksimum $>13,8 \mathrm{~m} / \mathrm{s}$ mencapai $12,8 \%$.

Untuk perubahan arah dan kecepatan angin maksimum pada tiap musimnya selama Tahun 2001 2013, sebagaimana disajikan pada Tabel $(3.2-3.5)$ dan Gambar (3.4 - 3.7) menunjukkan bahwa untuk daerah Tanah Bumbu termasuk lokasi studi, pada musim barat (bulan Desember - Februari) arah angin dominan berasal dari barat $(48,7 \%)$, dengan kecepatan dominan berkisar pada interval 7,9 - 10,7 m/s (38,5\%), sedangkan kecepatan $>13,8 \mathrm{~m} / \mathrm{s}$ mencapai $25,6 \%$.
Pada musim peralihan I (bulan Maret - Mei), arah angin sudah berubah dan lebih bervariasi, dengan arah terbanyak dari utara $(25,6 \%)$ kemudian dari arah barat laut dan selatan (masing-masing 23,1\%) dengan kecepatan dominan menurun pada interval 5,4-7,9 m/s (46,2\%). Pada musim timur (bulan Juni - Agustus) kecepatan angin sudah dominan dari selatan yakni $33,3 \%$, demikian juga kecepatannya masih dominan pada interval $5,4-7,9 \mathrm{~m} / \mathrm{s} \quad(48,7 \%)$. Data angin maksimum tahunan di Kalimantan dapat dilihat pada Tabel 1 berikut:

\begin{tabular}{|c|c|c|c|c|c|c|c|c|c|c|c|c|}
\hline \multirow{2}{*}{$\begin{array}{c}\text { Wind } \\
\text { Direc } \\
\text { tion }\end{array}$} & \multicolumn{2}{|c|}{$\begin{array}{c}0-5,4 \\
\mathrm{~m} / \mathrm{s}\end{array}$} & \multicolumn{2}{|c|}{$\begin{array}{c}5,4-7,9 \\
\mathrm{~m} / \mathrm{s}\end{array}$} & \multicolumn{2}{|c|}{$\begin{array}{c}7,9-10,7 \\
\mathrm{~m} / \mathrm{s}\end{array}$} & \multicolumn{2}{|c|}{$\begin{array}{c}10,7-13,8 \\
\mathrm{~m} / \mathrm{s}\end{array}$} & \multicolumn{2}{|c|}{$\begin{array}{c}\geq 13,8 \\
\mathrm{~m} / \mathrm{s}\end{array}$} & \multicolumn{2}{|c|}{ Total } \\
\hline & $\begin{array}{l}\begin{array}{l}\text { Fr } \\
\text { ek }\end{array} \\
\end{array}$ & $\%$ & $\begin{array}{l}\begin{array}{l}\text { Fr } \\
\text { ek }\end{array} \\
\end{array}$ & $\%$ & $\begin{array}{c}\text { Fre } \\
\mathbf{k}\end{array}$ & $\%$ & $\begin{array}{l}\text { Fr } \\
\text { ek }\end{array}$ & $\%$ & $\begin{array}{l}\mathrm{Fr} \\
\text { ek }\end{array}$ & $\%$ & $\begin{array}{l}\text { Fr } \\
\text { ek }\end{array}$ & $\%$ \\
\hline $\mathbf{N}$ & 4 & 2,6 & 11 & 7,1 & 6 & 3,8 & 1 & 0,6 & 2 & 1,3 & 24 & 15 \\
\hline NE & 1 & 0,6 & - & - & - & - & - & - & 1 & 0,6 & 2 & 1,3 \\
\hline $\mathbf{E}$ & 2 & 1,3 & 2 & 1,3 & 1 & 0,6 & 2 & 1,3 & 3 & 1,9 & 10 & 6,4 \\
\hline SE & 4 & 2,6 & 10 & 6,4 & 3 & 1,9 & - & - & - & - & 17 & 10 \\
\hline $\mathbf{S}$ & 5 & 3,2 & 24 & 15,4 & 6 & 3,8 & 4 & 2,6 & 3 & 1,9 & 42 & $\begin{array}{c}26, \\
9\end{array}$ \\
\hline SW & - & - & 2 & 1,3 & 7 & 4,5 & 2 & 1,3 & 3 & 1,9 & 14 & 9,0 \\
\hline $\mathbf{W}$ & - & - & 9 & 5,8 & 11 & 7,1 & 2 & 1,3 & 7 & 4,5 & 29 & $\begin{array}{c}18, \\
6\end{array}$ \\
\hline NW & 1 & 0,6 & 8 & 5,1 & 7 & 4,5 & 1 & 0,6 & 1 & 0,6 & 18 & $\begin{array}{c}11, \\
5\end{array}$ \\
\hline Total & 17 & $\begin{array}{c}10, \\
9\end{array}$ & 66 & 42,3 & 41 & $\begin{array}{c}26, \\
3\end{array}$ & 12 & 7,7 & 20 & $\begin{array}{c}12, \\
8\end{array}$ & $\begin{array}{c}15 \\
6\end{array}$ & $\begin{array}{c}10 \\
0\end{array}$ \\
\hline
\end{tabular}

Tabel 1. Frekuensi dan persentase angin maksimum

Sumber: Analisis Data (2014)

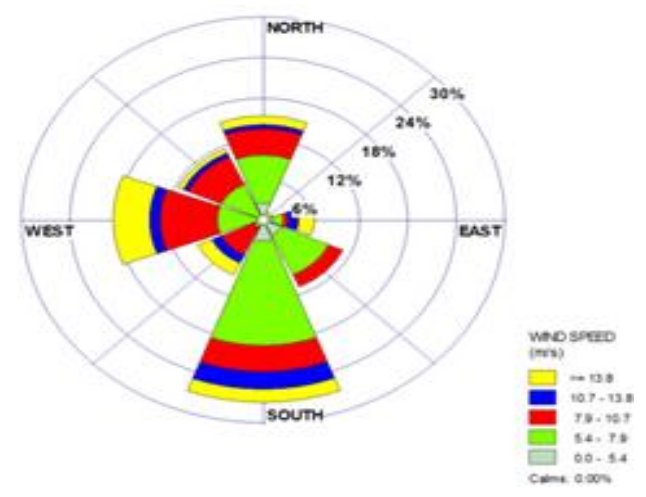

Gambar 3Wind Rose selama tahun 2001-2013 di daerah Tanah bumbu

Sumber: Pengolahan Data (2013)

Dari wind rose diatas terlihat bahwa arah angin yang dominan adalah arah angin dari selatan.

\section{Pasang Surut}

- Konstanta harmonik pasang surut

Hasil analisis harmonik pasut dengan Metode Admiralty, diperoleh 9 (sembilan) konstanta harmonik utama untuk amplitudo (A) dan beda fase $\left(\mathrm{g}^{\circ}\right)$ pada perairan Batulicin Selat Laut (Kabupaten Tanah Bumbu) sebagaimana disajikan pada Tabel 2 .Hasil analisis konstanta transpor pasang surut di perairan Batulicin Selat Laut (Kabupaten Tanah Bumbu) 
Tabel 2 Konstanta pasang surut

\begin{tabular}{|c|c|c|c|c|c|c|c|c|c|c|}
\hline $\begin{array}{c}\text { Konsta } \\
\text { nta } \\
\text { Pasang } \\
\text { Surut }\end{array}$ & $S_{o}$ & $\mathbf{M}_{2}$ & $\mathbf{S}_{2}$ & $\mathbf{N}_{2}$ & $\mathbf{K}_{1}$ & $O_{1}$ & $\begin{array}{c}\text { M } \\
4\end{array}$ & $\begin{array}{l}\mathbf{M} \\
\mathbf{S}_{4}\end{array}$ & $\mathbf{K}_{2}$ & $\mathbf{P}_{1}$ \\
\hline $\mathrm{A} \mathrm{cm}$ & 170 & 37 & 35 & 8,1 & 40,4 & 27 & $\begin{array}{l}1, \\
6\end{array}$ & $\begin{array}{c}3, \\
0\end{array}$ & 9 & 13 \\
\hline $\mathbf{g}^{\circ}$ & & 130 & 225 & 66, & 308 & 289 & $\begin{array}{r}10 \\
2\end{array}$ & $\begin{array}{r}12 \\
2\end{array}$ & 225 & 308 \\
\hline
\end{tabular}

Sumber :Hasil Analisis (2013).

\section{- $\quad$ Tipe pasang surut}

Berdasarkan nilai konstanta harmonik pasang surut yang didapatkan, maka diperoleh bilangan Formzahl (F) sebesar 0,93 untuk perairan Batulicin dan 0,66 untuk perairan Tarjun. Berdasarkan kriteria courtier range kedua nilai tersebut termasuk dalam tipe pasang surut tipe campuran condong keharian ganda (mixed tide prevailing semidiurnal). Hal ini dapat dilihat pada Gambar 3. menunjukkan dalam satu hari terjadi dua kali air pasang dan dua kali air surut, tetapi tinggi dan periodenya berbeda. Selain itu hasil ini juga dilakukan peramalan dengan menggunakan program pasut yang dikembangkan oleh BPPT (1998) berdasarkan input konstanta yang diperoleh).

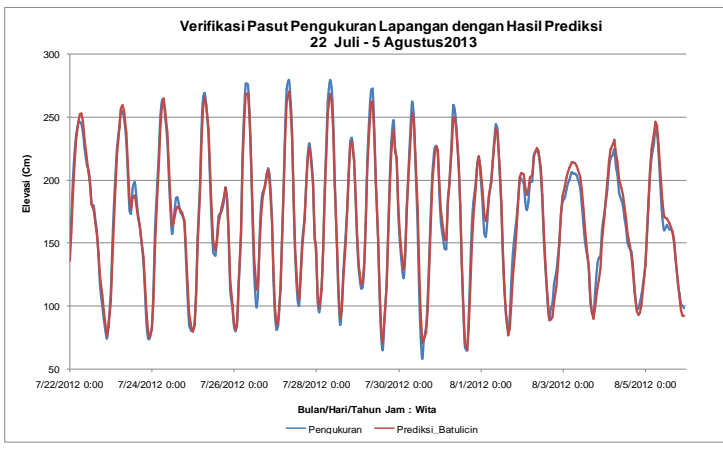

Gambar 4 diagram pasang surut

Sumber: Hasil anilisis (2013)

- Tunggang air pasang surut

Tunggang air pasang surut pada penelitian ini menggunakan datum referensi terhadap MSL (Mean Sea Level) artinya kedalaman MSL adalah 0 (nol). Pada Tabel 3.8 (perairan Batulicin) disajikan tunggang air pasang surut untuk tipe pasang surut semi diurnal.

Untuk perairan Batulicin nilai tunggang air pasang surut untuk pasang purnama (spring tide), pada air tinggi ratarata pasang (MHHWS) sebesar 243,01 cm atau sebesar $72,93 \mathrm{~cm}$ di atas MSL dan air rendah pada rata-rata surut (MLLWS) adalah 70,03 $\mathrm{cm}$ atau $-72,93 \mathrm{~cm}$ di bawah MSL. Untuk nilai tunggang air pasang surut pada saat pasang perbani (neap tide), air tinggi rata-rata pasang (MHHWN) sebesar $172,83 \mathrm{~cm}$ atau sebesar $2,76 \mathrm{~cm}$ di atas MSL sedang untuk air rendah pada ratarata surut (MLLWN) sebesar $167,31 \mathrm{~cm}$ atau $-2,76$ cm di bawah MSL. Untuk nilai Air tinggi tertinggi pada pasang besar (HAT) adalah $311,17 \mathrm{~cm}$ atau $141,10 \mathrm{di}$ atas MSL dan nilai air rendah terendah pada surut besar (LAT) adalah 28,97 $\mathrm{cm}$ atau -141,10 di bawah MSL. Untuk nilai tunggang pasang surut (tidal range) pada saat pasang purnama yaitu antara MHHWS dan MLLWS adalah 172,98 cm.

\section{Arus}

Arus merupakan faktor yang berperan dalam penentuan bangunan pantai (untuk mencegah abrasi atau sedimentasi seperti jetty), karena arah dan kecepatan arus dapat menentukkan letak dan posisi bagunan pantai tersebut, selain itu dapat juga digunakan dalam menentukkan kelayakan pelabuhan, karena berhubungan dengan proses sedimentasi (pengerukan).

Berdasarkan hasil pengukuran arus yang dilakukan selama 26 jam pada kondisi kedalaman yang berbeda yakni 0,2 d, 0,6 d dan 0,8 d, sebagaimana disajikan pada Tabel 3.9. Dari table tersebut menunjukan bahwa arah arus pada saat pasang akan bergerak menuju arah barat daya - selatan $\left(180-230^{\circ}\right)$ dengan kecepatan berkisar $0,056-0,44 \mathrm{~m} / \mathrm{s}$ dan pada saat surut akan bergerak menuju utara - timur laut (20 $80^{\circ}$ ) dengan kecepatan berkisar 0,122 - 0,612 m/s pada kedalaman 0,2d. Demikian halnya juga pada kedalaman 0,6 d, akan tetapi memiliki kecepatan yang lebih besar, sedangkan pada kedalaman 0,8 d lebih lambat. Perbedaan ini disebabkan karena faktor lokasi studi yang berada di selat, sehingga pengaruh pasang surut dan arah angin terutama mempengaruhi pada daerah permukaan dan intermedit (tengah), sedangkan di dekat dasar pengaruh pasang surut dan arah angin akan semakin berkurang akan tetapi faktor topografi dasar laut akan memperlambat gaya pergerakan air (gaya friksi).

Hasil pengukuran ini jika dibandingkan dengan hasil model diatas menunjukkan pola yang sama yakni pada saat pasang, pola arus akan bergerak menuju bagian utara perairan Selat Laut, sedangkan pada saat surut pola arus akan bergerak menuju bagian selatan perairan Selat Laut,meskipun dengan kecepatan yang berbeda. Perbedaan ini disebabkan karena banyak faktor yang mempengaruhi arah dan kecepatan arus diantaranya pasang surut, gelombang, angin, kedalaman, curah hujan, debit sungai, suhu dan parameter fisik lainnya, sedangkan hasil model hanya mempertimbangkan kondisi pasang surut dan kedalaman.

\section{Gelombang}

Hasil analisis parameter gelombang setiap musim selama Tahun 2004 - 2015dapat dilihat pada tabel 3 berikut: 


\begin{tabular}{|c|c|c|c|c|c|c|c|c|c|}
\hline Musim & Arah & $\mathbf{F}(\mathbf{m})$ & $\begin{array}{c}\mathbf{U}^{*} \\
(\mathbf{m} / \mathbf{s})\end{array}$ & $\begin{array}{r}H_{m o} \\
(\mathbf{m})\end{array}$ & $\mathbf{T}(\mathbf{s})$ & Lo & $\mathbf{H b}$ & db & $\begin{array}{c}\text { Jumlah } \\
(\%)\end{array}$ \\
\hline \multirow{4}{*}{ Barat } & Utara & 7500 & 0,53 & 0,6 & 2,3 & 7,9 & 0,55 & 0,7 & 12,50 \\
\hline & $\begin{array}{c}\text { Timur } \\
\text { Laut }\end{array}$ & 7900 & 0,54 & 0,6 & 2,3 & 8,3 & 0,58 & 0,8 & 12,50 \\
\hline & Tenggara & 12000 & 0,34 & 0,5 & 2,3 & 8,0 & 0,47 & 0,6 & 12,50 \\
\hline & Selatan & 15000 & $0,28-0,57$ & $\begin{array}{l}0,5- \\
0,9\end{array}$ & $\begin{array}{l}2,3- \\
2,9\end{array}$ & $\begin{array}{l}8,2- \\
13,3\end{array}$ & $\begin{array}{c}0,44- \\
0,86\end{array}$ & $\begin{array}{l}0,6- \\
1,1\end{array}$ & 62,50 \\
\hline \multirow{4}{*}{$\begin{array}{l}\text { Peralihan } \\
\text { I }\end{array}$} & Utara & 7500 & $0,23-0,52$ & $\begin{array}{l}0,3- \\
0,6\end{array}$ & $\begin{array}{l}1,7- \\
2,2\end{array}$ & $\begin{array}{l}4,6- \\
7,8\end{array}$ & $\begin{array}{l}0,26- \\
0,55\end{array}$ & $\begin{array}{l}0,3- \\
0,7\end{array}$ & 33,33 \\
\hline & $\begin{array}{l}\text { Timur } \\
\text { Laut }\end{array}$ & 7900 & 0,24 & 0,28 & 1,76 & 4,85 & 0,27 & 0,35 & 5,56 \\
\hline & Timur & 3200 & $0,23-0,60$ & $\begin{array}{l}0,2- \\
0,5\end{array}$ & $\begin{array}{l}1,3- \\
1,8\end{array}$ & $\begin{array}{l}2,6- \\
4,9 \\
\end{array}$ & $\begin{array}{c}0,16- \\
0,40\end{array}$ & $\begin{array}{l}0,2- \\
0,5\end{array}$ & 16,67 \\
\hline & Selatan & 15000 & $0,25-0,53$ & $\begin{array}{l}0,4- \\
0,9\end{array}$ & $\begin{array}{l}2,2- \\
2,8\end{array}$ & $\begin{array}{l}7,6- \\
12,6\end{array}$ & $\begin{array}{c}0,40- \\
0,80\end{array}$ & $\begin{array}{l}0,5- \\
1,0\end{array}$ & 44,44 \\
\hline \multirow{4}{*}{ Timur } & Utara & 7500 & $0,22-0,30$ & $\begin{array}{l}0,3- \\
0,3\end{array}$ & $\begin{array}{l}1,7- \\
1,9\end{array}$ & $\begin{array}{l}4,4- \\
5,4 \\
\end{array}$ & $\begin{array}{l}0,24- \\
0,32\end{array}$ & $\begin{array}{l}0,3- \\
0,4\end{array}$ & 19,23 \\
\hline & Timur & 3200 & $0,42-0,62$ & $\begin{array}{c}0,3- \\
0,5\end{array}$ & $\begin{array}{l}1,6- \\
1,8\end{array}$ & $\begin{array}{c}3,8- \\
5,0\end{array}$ & $\begin{array}{c}0,28- \\
0,41\end{array}$ & $\begin{array}{l}0,4- \\
0,5\end{array}$ & 19,23 \\
\hline & Tenggara & 12000 & $0,23-0,35$ & $\begin{array}{c}0,3- \\
0,5\end{array}$ & $\begin{array}{l}2,0- \\
2,3\end{array}$ & $\begin{array}{r}6,2- \\
8,3\end{array}$ & $\begin{array}{c}0,33- \\
0,49\end{array}$ & $\begin{array}{l}0,4- \\
0,6\end{array}$ & 26,92 \\
\hline & Selatan & 15000 & $0,24-0,41$ & $\begin{array}{l}0,4- \\
0,7\end{array}$ & $\begin{array}{l}2,2- \\
2,6\end{array}$ & $\begin{array}{l}7,4- \\
10,5\end{array}$ & $\begin{array}{c}0,38- \\
0,62\end{array}$ & $\begin{array}{l}0,5- \\
0,8\end{array}$ & 34,62 \\
\hline \multirow{4}{*}{$\begin{array}{l}\text { Peralihan } \\
\text { II }\end{array}$} & Utara & 7500 & $0,34-0,44$ & $\begin{array}{l}0,4- \\
0,5\end{array}$ & $\begin{array}{l}1,9- \\
2,1\end{array}$ & $\begin{array}{l}5,9- \\
7,0\end{array}$ & $\begin{array}{l}0,36- \\
0,47\end{array}$ & $\begin{array}{l}0,5- \\
0,6\end{array}$ & 11,11 \\
\hline & timur & 3200 & 0,25 & 0,19 & 1,32 & 2,72 & 0,17 & 0,22 & 5,56 \\
\hline & Tenggara & 12000 & $0,32-0,41$ & $\begin{array}{l}0,5- \\
0,6\end{array}$ & $\begin{array}{l}2,2- \\
2,4\end{array}$ & $\begin{array}{l}7,7- \\
9,1\end{array}$ & $\begin{array}{l}0,44- \\
0,55\end{array}$ & $\begin{array}{l}0,6- \\
0,7\end{array}$ & 27,78 \\
\hline & Selatan & 15000 & $0,21-0,48$ & $\begin{array}{l}0,3- \\
0,8\end{array}$ & $\begin{array}{l}2,1- \\
2,8\end{array}$ & $\begin{array}{l}6,8- \\
11,8\end{array}$ & $\begin{array}{c}0,37- \\
0,74\end{array}$ & $\begin{array}{l}0,4- \\
0,9\end{array}$ & 55,56 \\
\hline
\end{tabular}

Tabel 3 parameter gelombang tahun 2004-2015

Sumber : Hasil analisis (2015)

Perairan bagian selatan Kabupaten Tanah Bumbu merupakan daerah yang relatif cukup terbuka dari serangan gelombang laut dalam. Berdasarkan hasil analisis di atas, menunjukkan bahwa bentuk dan tata letak konstruksi pelabuhan/bangunan pantai yang akan dikembangkan harus memperhatikan faktor serangan gelombang tersebut. Hal ini akan sangat berpengaruh baik pada saat konstruksi maupun saat berlangsungnya kegiatan.

\section{HASIL DAN PEMBAHASAN}

\section{Kapal rencana}

Dermaga pelabuhan peti kemas Batu Licin direncanakan akan melayani kapal peti kemas 50000 DWT. Berikut adalah data kapal yang akandigunakan pada proses desain Dermagapelabuhan peti kemas Batu licin.

$\begin{array}{ll}\text { Tipe Kapal } & =\text { Kapal peti kemas } \\ \text { Tonase } & =50.000 \text { DWT } \\ \text { Panjang (Loa) } & =216 \mathrm{~m} \\ \text { Lebar (B) } & =31,5 \mathrm{~m} \\ \text { Draft penuh } & =12,4 \mathrm{~m}\end{array}$

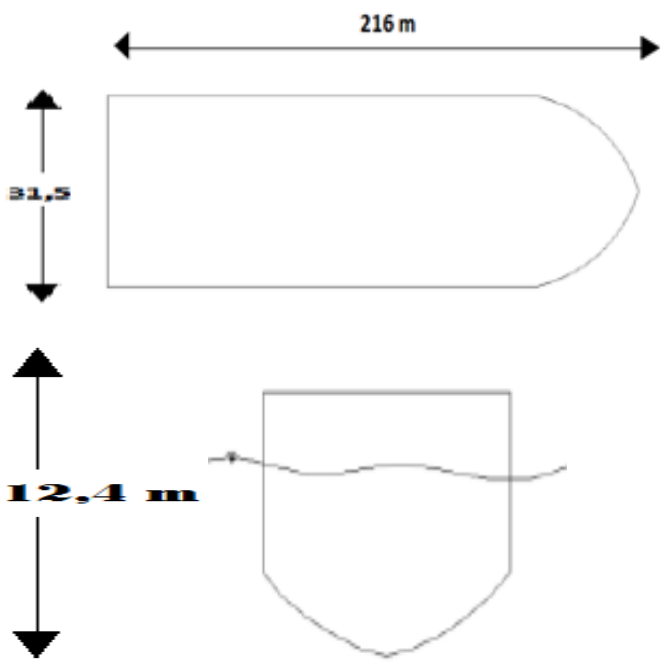

Gambar 5. Karakteristik kapal rencana Sumber : Triatmojo (2010)

\section{Kolam dermaga}

Dengan rencana layout yang menggunakan jalur keluar masuk yang berbeda maka lebar untuk perputaran Kapal tidak diperhitungkan. Hanya memperhitungkan lebar basin yaitu :

$\begin{array}{rlrlrl}\text { Panjang } & = & 1,25 & \mathrm{x} & \text { LOA } & \\ & = & 1,25 & \mathrm{x} & 216 & \mathrm{M} \\ & = & 270 & \approx & 275 & \mathrm{M} \\ \text { Lebar } & = & 1,25 & \mathrm{x} & \mathrm{B} & \\ & = & 1,25 & \mathrm{x} & 31,5 & \\ & = & 39,375 & \mathrm{~m} & & \end{array}$

\section{Kedalaman perairan}

$\begin{array}{rlrll}\mathrm{H} & = & 1,1 & \mathrm{x} & \text { Draft Kapal } \\ & = & 1,1 & \mathrm{x} & 12,4 \\ & = & 13,64 & \approx & 14 \mathrm{~m}\end{array}$

\section{Tuning Basin}

Dalam perencanaan ini kapal diasumsikan bermanuver tanpa dipandu jadi diameter tuning basin adalah :

$\mathrm{Db}$

$$
\begin{array}{lrlll}
= & 4 & \mathrm{x} & \text { LOA } \\
= & 4 & \mathrm{x} & 216 \\
= & 864 & \mathrm{M} &
\end{array}
$$

Panjang dermaga

Panjang dermaga untuk satu tambatan, yaitu sama dengan panjang kapal terbesar yang menggunakan dermaga ditambah masing-masing $10 \%$ panjang kapal di ujung hulu dan buritan kapal.

$$
\begin{aligned}
\mathrm{Lp} & =\text { n.Loa }-(\mathrm{n}-1) 15+50 \\
& =3 \mathrm{x} \quad 216+\left(\begin{array}{llll} 
& 3- & 1
\end{array}\right) \quad 15 \quad+? 0
\end{aligned}
$$

Lebar dermaga

Dalam perncanaan ini lebar dermaga direncanakan 50 meter dengan lebar spam untuk gantry crane sebesar $16 \mathrm{~m}$. tipe gantry crane yang digunakan adalah Rubber Tyred Gantry yaitu tipe gantry cane yang menggunakan roda untuk berpindah tempat. Untuk stacking area di bawah jalur gantry crane 
adalah selebar 4 peti kemas dengan tinggi maksimal dua tumpukan. lalu lintas peti kemas untuk keluar masuk ke area dermaga menggunakan trailer dengan jalur satu arah. setelah kapal merapat, peti kemas diturunkan oleh gantry crane ke stacking area untuk sementara waktu. kemudian peti kemas diangkut menggunakan trailer secara berurutan.

\section{Elevasi dermaga}

Elevasi dermaga didapat dari elevasi hasil perhitungan pasang surut (HHWL) ditambah tinggi gelombang yang terjadi akibat angina/fetch $(0,42 \mathrm{~m})$ dan ditambah tinggi jagaan $(0.5 \mathrm{~m})$.

\section{Perencanaan dan pemilihan tipe fender}

Dari perhitungan sebelumnya didapatkan nilai $\mathrm{Ef}=27,5$ ton, maka dipilih tipe fender karet super seibu tipe V $400 \mathrm{H}$ yang memiliki gaya serap batas bawah dan atas 24.12-30.37 ton dan energi yang diteruskan 3.0-4.0 ton, untuk defleksi $45 \%$.

Tabel 4. Tipe fender

\begin{tabular}{ccccc}
\hline \multirow{2}{*}{ Tipe Fender } & \multicolumn{2}{c}{ CA } & \multicolumn{2}{c}{ CB } \\
\cline { 2 - 5 } & R.F. (ton) & $\begin{array}{c}\text { E.A. } \\
\text { (ton) }\end{array}$ & $\begin{array}{c}\text { R.F. } \\
\text { (ton) }\end{array}$ & $\begin{array}{c}\text { E.A. } \\
\text { (ton) }\end{array}$ \\
\hline KVF 200 H & 15.35 & 1.0 & 12.60 & 0.75 \\
\hline KVF 250 H & 19.52 & 1.6 & 15.30 & 1.18 \\
\hline KVF 300 H & 23.07 & 2.2 & 17.48 & 1.60 \\
\hline KVF 400 H & 30.37 & 4.0 & 24.12 & 3.00 \\
\hline KVF 500 H & 38.40 & 6.2 & 30.01 & 4.60 \\
\hline KVF 600 H & 45.59 & 9.0 & 34.30 & 6.50 \\
\hline KVF 800 H & 60.74 & 16.0 & 48.17 & 12.0 \\
\hline KVF 1000 H & 75.96 & 25.0 & 60.29 & 18.00 \\
\hline Sumyyyyyy
\end{tabular}

Sumber : Triatmojo (2010)

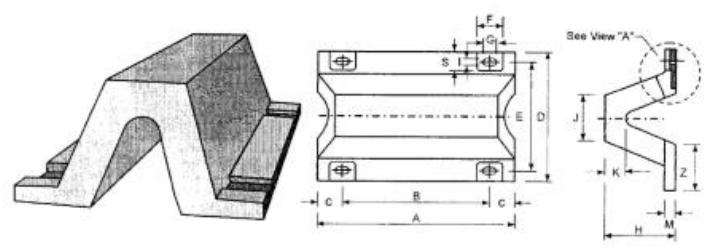

Gambar 6.fender karet karet seibu tipe V Sumber : Triatmojo (2010)

\section{Perencanaan Boulder}

Pada pembahasan sebelumnya telah dijelaskan untuk kapal 20.001-50.000 DWT diperoleh jarak maksimal pemasangan boulder adalah $35 \mathrm{~m}$ dan jumlah minimum tambatan 13 buah. Maka, diambil jumlah tambahan 13 buah dengan jarak $18 \mathrm{~m}$

Perencanaan Balok

1. Balok Memanjang

Balok memanjang direncanakan dengan ukuran $120 \mathrm{~cm}$ x $80 \mathrm{~cm}$

Momen positif : $781.042 .837,0 \mathrm{~N}-\mathrm{mm}$

Momen negatif : $-1.150 .112 .909,0 \mathrm{~N}-\mathrm{mm}$

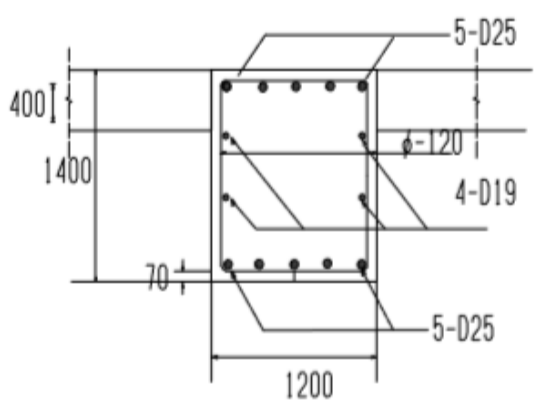

Gambar penulangan balok memanjang Sumber : Analisis Data (2017)

2. Balok Melintang

Balok melintang direncanakan dengan ukuran $120 \mathrm{~cm} \times 80 \mathrm{~cm}$

Momen positif : $746.126 .709 \mathrm{~N}-\mathrm{mm}$

Momen negatif : $-1.422 .547 .363 \mathrm{~N}-\mathrm{mm}$

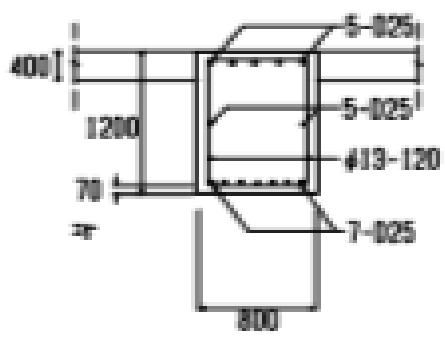

Gambar 7. penulangan balok memanjang

Sumber : Analisis Data (2017)

3. Balok Crane

Balok Crane direncanakan dengan ukuran 120 $\mathrm{cm} \times 80 \mathrm{~cm}$

Momen positif : 823.956.328 N-mm

Momen negatif : $-1.745 .932 .403 \mathrm{~N}-\mathrm{mm}$

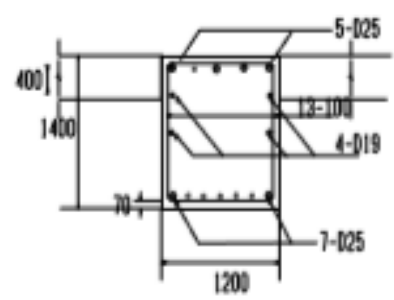

Gambar 8. penulangan balok memanjang Sumber : Analisis Data (2017)

\section{Perencanaan Plat}

Mutu Beton (fc')

Tebal Plat (t)

$=35,0 \mathrm{MPa}$

Tebal decking $(\mathrm{td})$

$=400,0 \mathrm{~mm}$

Dia $<13 \mathrm{~mm}$,Mutu Baja (fy) $=240,0 \mathrm{MPa}$

Dia $>13 \mathrm{~mm}$,Mutu Baja (fy) $=390,0 \mathrm{MPa}$

$$
\begin{array}{rll}
\varphi & = & 0,8 \\
\beta 1 & = & 0,78
\end{array}
$$


Diambil contoh perhitungan balok tipe A. berikut gambar balok tipe A:

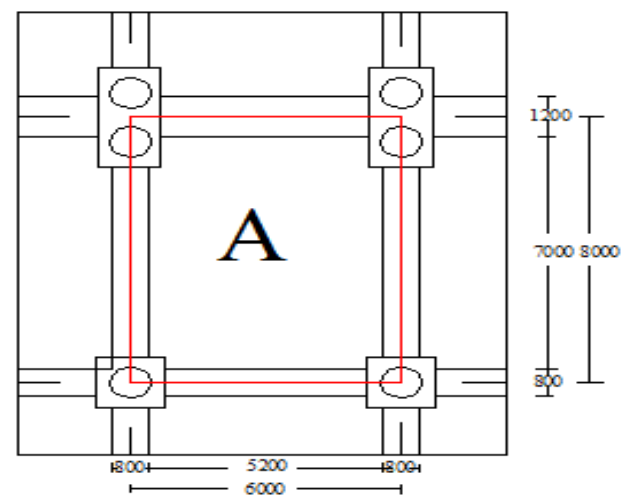

Gambar 9 pelat tipe A

Sumber : Analisis data (2017)

Dari perhitungan struktur untuk lantai dermaga (tipe A), maka didapat rekapitulasi tulangan sebagai berikut:

Tabel 5. tulangan pelat $\mathrm{A}$

\begin{tabular}{llll}
\hline \multicolumn{4}{c}{ Tukangan terpasang } \\
\hline \multicolumn{2}{c}{ Tumpuan } & \multicolumn{2}{c}{ Lapangan } \\
\hline Arah x & Arah y & Arah x & Arah y \\
\hline D22-120 & D22-100 & D22-120 & D22-100 \\
\hline
\end{tabular}

Sumber : Analisis data (2017)

\section{Perhitungan Poer Dermaga}

Perhitungan Poer Dermaga dianalisa berdasarkan gayagaya maksimum yang bekerja pada balok tertumpu pada poer. Ada dua tipe poer yang digunakan pada perencanaan yaitu :

1. Poer Tunggal

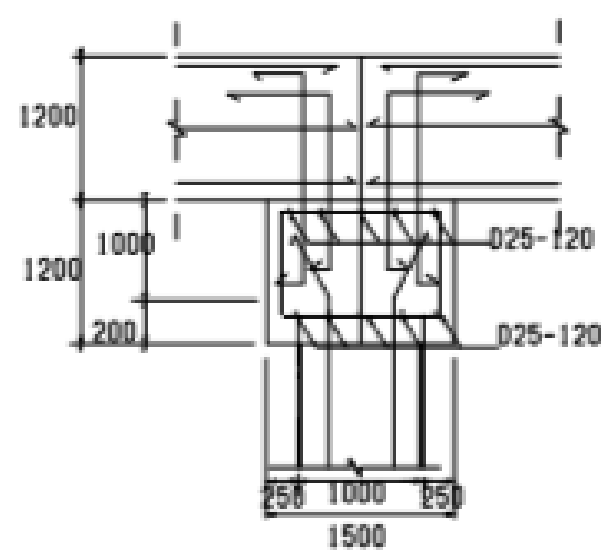

Gambar 10. penulangan poer tunggal

Sumber : Analisis data (2017)

\section{Poer Ganda}

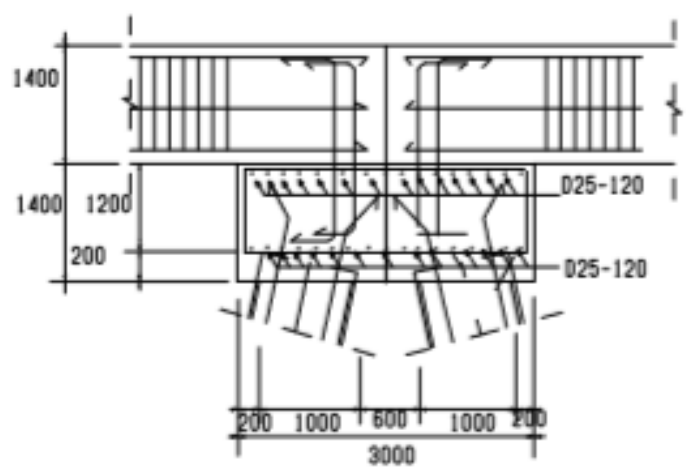

Gambar 11. penulangan poer tunggal

Sumber : Analisis data (2017)

Berdasarkan perhitungan struktur untuk poer dermaga didapatkan tulangan sebagai berikut:

Tabel 6. Tulangan Poer

\begin{tabular}{lcc}
\hline jenis poer & tul. Utama & Tul. Geser \\
\hline tunggal & D25-150 & D13-200 \\
\hline ganda & D25-150 & D13-150 \\
\hline
\end{tabular}

Sumber : Analisis data (2017)

\section{KESIMPULAN}

Dari hasil Perencanaan Dermaga KAPET Batulicin dapat diambil beberapa kesimpulan sebagai berikut :

1. Dermaga Pelabuhan Batulicin terletak di pantai Desa Sendangmulyo, Kecamatan Sluke, Kabupaten Tanah bumbu, Provinsi Kalimantan Selatan. Pembangunan dermaga ini, bertujuan untuk melayani kapal Peti Kemas 50.000 DWT dan untuk memaksimalkan distribusi barang komoditas di daerah Tanah Bumbu dan sekitarnya.

2. Fender yang digunakan adalah Fender karettipe v $400 \mathrm{H}$.

3. Bollard yang digunakan yaitu bollard tipe BR-150 sebanyak 13 unit dan dipasang tiap jarak $18 \mathrm{~m}$.

Tabel 7. Hasil analisa Struktur

\begin{tabular}{|c|c|c|c|c|c|}
\hline No. & $\begin{array}{l}\text { Strukt } \\
\text { ur }\end{array}$ & Tipe & $\begin{array}{l}\text { Mome } \\
\mathrm{n}(\mathrm{N}- \\
\mathrm{mm})\end{array}$ & & $\begin{array}{l}\text { Tulangan } \\
\text { Terpasang }\end{array}$ \\
\hline \multirow{3}{*}{1} & \multirow{3}{*}{ Pelat } & \multirow{3}{*}{ A } & \multicolumn{2}{|c|}{ Tumpuan } & \\
\hline & & & Arah X & 281.532 .330 & D22-120 \\
\hline & & & Arah Y & 253.056 .490 & D22-100 \\
\hline
\end{tabular}




\begin{tabular}{|c|c|c|c|c|c|}
\hline & & & Arah X & 296.377.320 & D22-120 \\
\hline & & & Arah Y & 270.632 .970 & D22-100 \\
\hline \multirow[t]{10}{*}{2} & Balok & $\begin{array}{l}\text { Melint } \\
\text { ang }\end{array}$ & \multicolumn{2}{|c|}{ Tumpuan } & \\
\hline & & & \multicolumn{2}{|l|}{-Lentur } & \\
\hline & & & Tarik & 746126709 & $12-\mathrm{D} 25$ \\
\hline & & & Tekan & -253780058 & 7-D25 \\
\hline & & & \multicolumn{2}{|c|}{ Lapangan } & \\
\hline & & & \multicolumn{2}{|l|}{-Lentur } & \\
\hline & & & Tarik & 1427363254 & 7-D25 \\
\hline & & & Tekan & 373325801 & $5-\mathrm{D} 25$ \\
\hline & & & Geser & -768949 & D13-200 \\
\hline & & & Torsi & 160341775 & 4-D19 \\
\hline \multirow[b]{2}{*}{3} & \multirow[b]{2}{*}{ Poer } & \multirow{2}{*}{$\begin{array}{c}\text { Tiang } \\
\text { Tungga } \\
1\end{array}$} & Arah x & 11933793 & D22-150 \\
\hline & & & Arah Y & & D22-150 \\
\hline \multirow{3}{*}{4} & Tiang & Tegak & \multicolumn{3}{|c|}{426,21 ton } \\
\hline & ng & & & & \\
\hline & & \multicolumn{2}{|c|}{ Kedalaman } & $-26,5 \mathrm{~m}$ & \\
\hline
\end{tabular}

Sumber : Hasil analisis (2017)

\section{SARAN}

Beberapa hal yang perlu diperhatikan dalam Perencanaan Dermaga Batu licin ini antera lain:

1. Dari hasil perencanaan diatas sebaiknya lahan untuk pengembangan pelabuhan khususnya dermaga disediakan yang lebih luas agar pembangunan dapat menjadi maksimal.

2. Agar Kapal Peti Kemas 50.000 DWT dapat bersandar pada Dermaga, maka perlu dilakukan pengerukan pada alur pelayaran minimal -14,5 m dan pengerukan pada kolam pelabuhan $-14 \mathrm{~m}$.

\section{DAFTAR PUSTAKA}

Asiyanto, 2013, Metode Konstruksi Bangunan Pantai, Jakarta: Universitas Idonesia

Firdaus, Badruttamam. 2009. Perencanaan Detail Dermaga dan Breakwater Pelabuhan Peti Kemas Tanjung Bulu pandan, Madura. Surabaya : PenerbitITS.

OCDI 2002, “The Overseas coastal area development institute of japan".
SKSNI 03 1726-2003.2002. Tata Cara Perencanaan Ketahanan Gempa Untuk Bangunan. Jakarta. Badan Standarisasi Nasional.

SKSNI 03 2847-2002.2002. Tata Cara Perencanaan Struktur Beton Untuk Bangunan Gedung. Jakarta: Badan Standarisasi Nasional.

SKSNI03 1729-2002. 2002. Tata Cara Perencanaan Struktur Baja Untuk Bangunan Gedung, Jakarta: Badan Standarisasi Nasional.

SNI 03-1726-2012. 2012 Tata Cara Perencanaan Ketahanan Gempa Untuk Bangunan Gedung. Jakarta : Badan Standardisasi Nasional

SNI T-02-2005. 2005 Standar Pembebanan untuk Jembatan, Jakarta : Badan Standarisasi Nasional. Standards For Port And Harbour Facilities in Japan(2002). Tokyo, Japan.

The Struktural Design of Heavy Duty Pavements for Port and other Insdutries, British Port Association, 1982

Triatmojo, Bambang, (1999), Teknik Pantai. Yogyakarta: Beta Offset

Triatmojo, Bambang, (2010), Perencanaan Pelabuhan. Yogyakarta: Beta Offset. 